\title{
Dos pruebas de confiabilidad interjueces y una descripción de los procedimientos del algoritmo David Liberman (ADL) para el análisis de relatos
}

\section{Two inter-judge reliability tests and a description of the procedures for the analysis of narrations in the David Liberman algorithm (DLA)}

\author{
David Maldavsky ${ }^{1}$ \\ Universidad de Ciencias Empresariales y Sociales, UCES, Argentina \\ Clara R. Roitman \\ APA/UCES, Argentina \\ L. Alvarez, J. M. Rembado, S. Plut, D. Scilletta, \\ UCES, Argentina \\ C. Tate de Stanley \\ APA/UCES, Argentina
}

(Recepción: Agosto 2009 - Aceptación: Diciembre 2009)

\begin{abstract}
Resumen
Este trabajo presenta primero dos pruebas de confiabilidad interjueces del algoritmo David Liberman (ADL) y luego una descripción de los procedimientos para el análisis de los relatos. La primera prueba de confiabilidad es de tipo cualitativo y testea todos los instrumentos del método, mientras que la segunda es cuantitativa y testea solo los instrumentos para el análisis de relatos. En cuanto a la descripción de los procedimientos para el análisis de relatos con el ADL, sobre todo se presentan los criterios en que se basa el proceso de producción de la muestra.

Palabras Clave: Algoritmo David Liberman, confiabilidad interjueces, análisis de relatos.
\end{abstract}

\begin{abstract}
This paper first presents two inter-judge reliability tests of the David Liberman algorithm (DLA) and second a description of the procedures for the analysis of narrations. The first reliability test is qualitative and focuses on all the tools of the method, while the second is quantitative and is concentrated just on the instruments for the analysis of narrations. The description of the procedures for the analysis of narrations focuses on the criteria applied in the process of production of the sample.

Key words: David Liberman algorithm, inter-judge reliability, analysis of narrations.
\end{abstract}

1 Correspondencia: David Maldavsky. Dirección postal: República Árabe Siria 3319, 5ºB, Buenos Aires, Argentina. C.P: 1425 Telefono: 5411-4802- 3842 E-Mail: dmaldavsky@elsitio.net 